\title{
AOR
}

Selected Papers of \#AolR2018:

The $19^{\text {th }}$ Annual Conference of the

Association of Internet Researchers

Montréal, Canada / 10-13 October 2018

\section{NOT SUFFERING FOOLS GLADLY: CRAFTING PROSOCIAL COMMUNITY IN ONLINE MULTIPLAYER MINECRAFT}

Kenzie Woodbridge

Royal Roads University, British Columbia Institute of Technology

Play is a central, social, constructive, and transformative human activity and formalized play in the form of games and game playing is a ubiquitous feature of twenty-first century social life. Seven hundred million people worldwide play games online with others (Spil Games, 2013). For most, the social aspects of multiplayer games are at least as important as the gameplay (Ducheneaut \& Moore, 2005; Ducheneaut, Moore \& Nickell, 2007; Wang \& Wang, 2008; Ratan, Chung, Shen, Williams, \& Poole, 2010; Whippey, 2010; Kaye \& Bryce, 2012; O'Connor, Longman, White, \& Obst, 2015; Potts, 2015, Osmanovic \& Pecchioni 2016). Online multiplayer games function as the modern equivalent to pubs, parks, or community centers (Williams, Ducheneaut, Xiong, Yee, \& Nickell, 2006; Ducheneaut et al., 2007) where players come together casually and find social learning (Ducheneaut \& Moore, 2005; Banks \& Potts, 2010; Ratan et al., 2010), social interaction (Lee-Leugner, 2013), and even community (Cole \& Griffiths, 2007; Ducheneaut et al., 2007; Poor \& Skoric, 2014; O’Connor et al., 2015, Riordan \& Scarf, 2016).

If a community is a social group in which members experience a pleasurable sense of belonging and significance (McMillan \& Chavis, 1986), then online gaming spaces are an importance source of community for many people of all ages and from all parts of the world. However, game social spaces range from supportive and kindly (Williams et al., 2006; Ratan et al., 2010; Whippey, 2010; Kaye \& Bryce, 2012; O'Connor et al., 2015) to hostile, violent, and bullying (Ballard \& Welch, 2015). Prosocial online multiplayer game communities should be available to those who desire them. The central question in this research is this: if it can be established that a multiplayer Minecraft server offers a prosocial community experience, how and why is that prosocial community constituted? This suggests three avenues of investigation. First, how do server design, gameplay, and interaction impact prosocial community experiences and to what extent can those elements encourage altruism, empathy, and helping? Second, what moderation

Suggested Citation (APA): Woodbridge, K. (2018, October 10-13). Not suffering fools gladly: Crafting prosocial community in online multiplayer Minecraft. Paper presented at AolR 2018: The $19^{\text {th }}$ Annual Conference of the Association of Internet Researchers. Montréal, Canada: AolR. Retrieved from http://spir.aoir.org. 
strategies make prosocial community more likely or sustainable? Third, how important are individual players, their motivations, and shared social learning to the prosociality of a community? To answer these questions, I have taken an interpretive, qualitative, twophase approach to my research.

\section{Methods}

In this research, my site of analysis has been Minecraft multiplayer culture and my methods - virtual ethnography and interpretive phenomenological analysis (IPA)-fit within the interpretive paradigm. This is appropriate because the concept at the heart of this research, community, itself exists primarily as an interpreted phenomenon.

In the first phase I applied the ethnographic practice of participant observation to playing Minecraft in two multiplayer servers selected for their apparent prosocial qualities. This observation totaled 140 hours. I then inductively coded my observations and experiences, and analyzed them through the lens of McMillan and Chavis' (1986) community theory. In the second phase, I conducted five in-depth phenomenological interviews with players I had encountered in the first phase and analyzed those interviews using IPA. Cultural knowledge gained during the first phase provided a rich contextual backdrop for understanding and interpreting participants' specific phenomenological experiences.

\section{Conclusions}

Given online games' centrality in modern sociality, the social climate of those spaces is important. Understanding how prosocial community is created and maintained is important, both for the players who spend their time and energy there, and for society as a whole. My expectation for this research was that although player motivation would be an important factor in determining whether a server was prosocial in orientation, design factors such as whether or not a game server preferenced mob-killing over construction would also have a significant influence on the prosociality of a server. However, it is clear from this research that it is the prosocial orientation of players and the commitment, social skill, and integrity of server moderators that is most key to creating and maintaining a prosocial gaming environment. Although game design can support prosociality, game design factors appear to be much less important overall, as prosocially-oriented players make more prosocial choices regarding whether and how to engage with less prosocial game design and content. As a result, for individuals wishing to create prosocial Minecraft communities, it is attracting the right players-and refusing entry to the wrong ones-that is most important. This research explores all of these factors in more depth, and also investigates what criteria prosocial players use to choose a server.

\section{References}

Ballard, M. E., \& Welch, K. M. (2015). Virtual warfare: Cyberbullying and cybervictimization in MMOG play. Games and Culture. Advance online publication. DOI: $10.1177 / 1555412015592473$ 
Banks, J., \& Potts, J. (2010). Towards a cultural science of videogames: Evolutionary social learning. The Journal of Cultural Science, 3(1), 1-17. Retrieved from http://www.culturalscience.org/journal/index.php/culturalscience/article/download/38/68

Cole, H., \& Griffiths, M. D. (2007). Social interactions in massively multiplayer online role-playing gamers. CyberPsychology \& Behavior, 10(4), 575-583. DOI: $10.1089 / \mathrm{cpb} .2007 .9988$

Ducheneaut, N. \& Moore, R.J. (2005). More than just 'XP': Learning social skills in massively multiplayer online games. Interactive Technology \& Smart Education, 2, 89-100. Retrieved from http://citeseerx.ist.psu.edu/viewdoc/download?doi=10.1.1.212.5985\&rep=rep1\&ty pe $=$ pdf

Ducheneaut, N., Moore, R.J., \& Nickell, E. (2007). Virtual "third places": A case study of sociability in massively multiplayer games. Computer Supported Cooperative Work, 16, 129-166. DOI: 10.1007/s10606-007-9041-8

Kaye, L.K. \& Bryce, J. (2012). Putting the "fun factor" into gaming: The influence of social contexts on experiences of playing videogames. International Journal of Internet Science, 7(1), 23-27. Retrieved from

http://repository.edgehill.ac.uk/4313/1/Putting_the_fun_factor_into_gaming._The _influence_of_social_contexts_on_experiences_of_playing_videogames.pdf

Lee-Leugner, J. (2013). Youth, gaming, and the network society: Exploring the agentic potential of gameplay in Minecraft (Master's thesis). Retrieved from http://summit.sfu.ca/item/12866

McMillan, D.W. \& Chavis, D.M. (1986). Sense of community: A definition and theory. Journal of Community Psychology, 14(1), 6-23. DOI: 10.1002/15206629(198601)14:1<6::AID-JCOP2290140103>3.0.CO;2-I

O'Connor, E.L., Longman, H., White, K.M., \& Obst, P.L. (2015). Sense of community, social identity and social support among players of massively multiplayer online games (MMOGs): A qualitative analysis. Journal of Community \& Applied Social Psychology, 25, 459-473. DOI: 10.1002/casp.2224

Osmanovic, S., \& Pecchioni, L. (2016). Beyond entertainment: Motivations and outcomes of video game playing by older adults and their younger family members. Games and Culture, 11(1-2), 130-149. DOI: $10.1177 / 1555412015602819$

Poor, N., \& Skoric, M. M. (2014). Death of a guild, birth of a network: Online community ties within and beyond code. Games and Culture, 9(3), 182-202.

DOI: 10.1177/1555412014537401 
Potts, A. (2015). 'Love you guys (no homo)'. Critical Discourse Studies, 12(2), 163-186. DOI: 10.1080/17405904.2014.974635

Ratan, R.A., Chung, J.E., Shen, C., Williams, D., \& Poole, M.S. (2010). Schmoozing and smiting: Trust, social institutions, and communication patterns in a MMOG. Journal of Computer-Mediated Communication, 16, 93-114. DOI: 10.1111/j.1083-6101.2010.01534.x

Riordan, B. C., \& Scarf, D. (2016). Crafting minds and communities with Minecraft. F1000Research 2017, 5(2339), 1-6. DOI: 10.12688/f1000research.9625.1

Spil Games. (2014). 2013 state of online gaming report. [corporate report] Retrieved from http://auth-83051f68-ec6c-44e0-afe5bd8902acff57.cdn.spilcloud.com/v1/archives/1384952861.25_State_of_Gaming_ 2013_US_FINAL.pdf

Wang, C. \& Wang, C. (2008). Helping others in online games: Prosocial behavior in cyberspace. Cyberpsychology \& Behavior, 11(3), 344-346. DOI: 10.1089/cpb.2007.0045

Whippey, C. (2010). Community in World of Warcraft: The fulfillment of social needs. Totem: The University of Western Ontario Journal of Anthropology, 18(1), 49-59. Retrieved from http://ir.lib.uwo.ca/totem/vol18/iss1/15

Williams, D., Ducheneaut, N., Xiong, L., Yee, N., \& Nickell, E. (2006). From tree house to barracks: The social life of guilds in World of Warcraft. Games and Culture, 1(4), 338-361. DOI: 10.1177/1555412006292616 